\title{
PENGARUH MODEL PEMBELAJARAN DISCOVERY LEARNING TERHADAP HASIL BELAJAR SISWA PADA MATA PELAJARAN DASAR LISTRIK DAN ELEKTRONIKA KELAS X INSTALASI TENAGA LISTRIK
}

\author{
Givson H. Siregar ${ }^{1}$; Hamonangan ${ }^{2}$ \\ 1,2Pendidikan Teknik Elektro Fakultas Teknik Unimed \\ 1'givsonsiregar4@gmail.com, ${ }^{2}$ hamtambun@gmail.com
}

\begin{abstract}
This research was conducted to find out whether there is an influence of the Discovery Learning learning model on student learning outcomes in the basic subjects of electricity and electronics for class X electrical power installations (TITL) in Vocational Schools for the 2019/2020 school year. This type of research is factorial. The population in this study were students of class X TITL SMK Negeri 1 Percut Sei Tuan and class X TITL students of SMKN 5 Medan. The sample of this study consisted of 2 classes, namely the experimental class which was taught using the Discovery Learning model and the control class which was taught using the Expository learning model. The data collection technique is done by using a test technique using multiple choice questions that have been tested for validity, reliability, level of difficulty and differentiating power of questions. The results showed that the results of hypothesis testing with the t-Ha test were accepted, there was an influence on the basic learning outcomes of electricity and electronics using the Discovery Learning learning model.
\end{abstract}

\section{Keywords: Discovery Learning Learning Model, Expository, Learning Outcomes.}

\begin{abstract}
Abstrak
Penelitian ini dilakukan untuk mengetahui apakah ada pengaruh model pembelajaran Discovery Learning terhadap hasil belajar siswapada mata pelajaran dasar listrik dan elektronika kelas $\mathrm{x}$ instalasi tenaga listrik (TITL) di SMK tahun ajaran 2019/2020. Jenis penelitian ini adalah Faktorial. Populasi dalam penelitian ini adalah siswa kelas X TITL SMK Negeri 1 Percut Sei Tuan dan siswa kelas X TITL SMKN 5 Medan. Sampel penelitian ini sebanyak 2 kelas yaitu kelas eksperimen yang diajarkan dengan menggunakan model pembelajaran Discovery Learning dan kelas kontrol yang diajarkan dengan model pembelajran Ekspositori. Teknik pengumpulan data dilakukan dengan teknik tes menggunakan soal pilihan ganda yang telah teruji validitas, realibilitas, tingkat kesukaran dan daya beda soal. Hasil penelitian menunjukkan bahwa hasil uji hipotesis dengan uji t Ha diterima, terdapat pengaruh hasil belajar dasar listrik dan elektronika dengan menggunakan model pembelajaran Discovery Learning.
\end{abstract}

Kata kunci : Model Pembelajaran Discovery Learning, Ekspositori, Hasil Belajar.

\section{PENDAHULUAN}

Pendidikan adalah pembelajaran pengetahuan, keterampilan, dan kebiasaan sekelompok orang yang diturunkan dari satu generasi ke generasi berikutnya melalui pengajaran, pelatihan, atau penelitian.Pendidikan merupakan hal yang sangat penting dalam membangun peradaban bangsa, bahkan pendidikan itu sama sekali tidak dapat dipisahkan dari kehidupan, baik dalam kehidupan keluarga, maupun dalam kehidupan bangsa dan Negara. Majunya suatu negara bahkan diukur dari kualitas pendidikannya.Dilihat dari sudut proses bahwa pendidikan adalah proses yang dapat mempengaruhi peserta didik supaya mampu menyesuaikan diri sebaik mungkin dengan lingkungannya akan menimbulkan perubahan dalam dirinya yang memungkinkan sehingga berfungsi sesuai kompetensinya dalam kehidupan masyarakat.

Sekolah Menengah Kejuruan adalah salah satu jenjang pendidikan menengah dengan kekhususan mempersiapkan lulusannya untuk siap bekerja,pendidikan kejuruan adalah bagian dari sistem pendidikan yang mempersiapkan seseorang agar lebih mampu bekerja pada suatu kelompok pekerjaan atau satu bidang pekerjaan daripada bidang-bidang pekerjaan lainnya. Dengan pengertian bahwa setiap bidang studi adalah pendidikan kejuruan sepanjang bidang studi tersebut dipelajari lebih mendalam dan kedalaman tersebut dimaksudkan sebagai bekal memasuki dunia kerja. Berbicara tentang pendidikan 
tidak dapat terlepas dari masalah pembelajaran, karena pembelajaran merupakan inti dari proses pendidikan. Peningkatan kualitas pendidikan menunjukkan pada upaya peningkatan kualitas proses dan hasil pembelajaran. Suatu sistem pendidikan disebut bermutu dari segi proses, jika proses belajar mengajar dapat berlangsung secara efektif dan siswa mengalami proses pembelajaran yang bermakna dan didukung oleh fasilitas dan sumber daya yang memadai maka sistem pendidikan tersebut dapat dikatakan bermutu.

Pembelajaran dapat menjadi bermakna karena berbagai faktor,salah satunya pengaruh model pembelajaran yang digunakan oleh guruuntuk menunjang proses belajar. Model pembelajaran merupakan salahsatu aspek yang penting dalam keberhasilan proses pembelajaran. Keberhasilan dari proses belajar mengajar dapat dilihat dari hasil belajar siswa. Hasil belajar merupakan perubahan tingkah laku yangterjadi pada siswa setelah mengalami proses pembelajaran. Sebagaimana hal ini dinyatakan oleh Bloom dalam Suprijono (2010:6) bahwa hasil belajar dapat diklasifikasikan ke dalam 3 kawasan yaitu kawasan kognitif, kawasan afektif, dan psikomotorik

Sekolah Menengah Kejuruan (SMK) berdasarkan Keputusan Direktur Jenderal Pendidikan Menengah Kemendikbud RI Nomor 7013/D/KP/2013 Tanggal 4 Desember 2013 tentang Spektrum Keahlian Pendidikan Menengah Kejuruan terdiri dari 9 (sembilan) bidang keahlian, yaitu (1) Teknologi dan Rekayasa; (2) Teknologi Informasi dan Komunikasi; (3) Kesehatan; (4) Agrobisnis dan Agroteknologi; (5) Perikanan dan Kelautan; (6) Bisnis dan Manajemen; (7) Pariwisata; (8) Seni Rupa dan Kriya; dan (9) Seni Pertunjukan. Selanjutnya, setiap bidang keahlian terdiri dari Pogram Keahlian, dan setiap program keahlian terdiri dari paket keahlian. Dengan demikian, spectrum keahlian pendidikan menengah kejuruan yang ditetapkan oleh Direktur Jenderal Manajemen Pendidikan Dasar dan Menengah Tahun 2013, terdiri dari 9 (Sembilan) bidang Keahlian, 46 (enam puluh enam) program keahlian, dan 128 paket keahlian.

Program Keahlian Teknik Ketenagalistrikan merupakan bagian dari bidang keahlian Teknologi dan Rekayasa yang mana memiliki paket keahlian berupa Teknik Pembangkit Tenaga Listrik, Teknik Jaringan Tenaga Listrik, Teknik Instalasi Pemanfaatan Tenaga Listrik, Teknik Otomasi Industri, dan Teknik Pendingin dan Tata Ruang. Sedangkan Program Keahlian Teknik Elektronika memiliki paket keahlian Teknik Ototronik, Teknik Audio Video, Teknik Elektronika Industri, Teknik Mekatronika, dan Teknik Elektronika Komunikasi.Dasar Listrik dan Elektronika (DLDE) adalah salah satu mata pelajaran dengan program keahliannya Teknik Instalasi Tenaga Listrik (TITL).

Dari hasil observasi yang dilakukan di SMK Negeri I Percut Sei Tuan dan SMKN 5 Medan diketahui bahwa model pembelajaran yang digunakan pada mata pelajaran DLDE adalah ekspositori dengan standar kriteria kelulusan minimal (KKM) pada mata pelajaran DLDE adalah 75. Sementara kenyataannya dilapangan rata-rata siswa belum mampu mencapai kriteria kelulusan minimal sebesar 75 , yang berarti hasil belajar siswa pada mata pelajaran DLDE kurang dari $75(<75)$.

Pada sistem pembelajaran model ekspositori, guru lebih banyak melakukan kegiatan belajarmengajar dengan bentuk ceramah. Pada saat mengikuti pembelajaran siswa sebatas memahami sambil membuat catatan, bagi yang merasa memerlukannya. guru menjadi pusat peran dalam pencapaian hasil pembelajaran dan seakan-akan menjadi satu-satunya sumber ilmu. Model ini berarti memberikan informasi satu arah karena yang ingin dicapai adalah bagaimana guru bisa mengajar dengan baik sehingga yang ada hanyalah transfer pengetahuan.

Proses pembelajaran yang lebih berpusat pada guru mengakibatkan siswa hanya memiliki pengalaman mendengar paparan saja. Output yang dihasilkan oleh pendekatan belajar seperti ini tidak lebih hanya menghasilkan siswa yang kurang mampu mengapresiasi ilmu pengetahuan, takut berpendapat, tidak berani mencoba yang akhirnya cenderung menjadi pelajaran yang pasif dan miskin kreativitas.

Terdapat beberapa model yang memungkinkan siswa untuk terampil dan paham secara mendalam melalui model tertentu diantaranya Discovery Learning. Hal itu didasarkan pada hasil penelitian dari para peneliti sebelumnya diantaranya Sani Ridwan(2014: 97) menyatakan Pembelajaran discovery learning berdampak positip pada kegiatan menemukankonsep melalui serangkaian data atau informasi yang diperoleh melaluipengamatan atau percobaanpembelajaran dan ditemukan suasana kelas yang lebih aktif. Hosnan (2014:282) menemukan bahwa model itu meningkatkan cara belajar aktif dengan menemukan sendiri, menyelidiki sendiri, dan ingatan setia dan tahan lama. Hal itu tampak dari hasil yang ditunjukkan dari cara berpikir analisis dan pemecahan masalah secara sendiri.

Penerapan model Discovery learning pada pembelajaran memungkinkan siswa lebih mudah memahami materi pelajaran,karena siswa bebas menyelidiki dan menarik kesimpulan dalam model itu. 
Guru bertindak sebagai fasilitator atau penunjuk jalan bagi siswa untuk membantu siswa mempergunakan ide, konsep, dan keterampilannya. Dalam materi pembelajaran menganalisis teorema rangkaian listrik arus searah, perlu adanya keaktifan siswa dalam mengikuti pembelajaran dikarenakan di dalam materi iniperlu pemahaman yang luas jika siswa tidak aktif dalam bertanya dan mencari jawaban maka pengetahuan mereka tentang materi tersebut tidak akan berkembang. Maka dari itu perlu dikaji penerapan model pembelajaran discovery learning dengan memperhatikan cara siswa menemukan serta memecahkan masalah sendiri (terkontrol) secara tuntas. Dalam hal ini siswa dituntut tuntas dalam pembelajarannya sehingga selain siswa diarahkan untuk penyelidikan, penemuan,dan pemecahan masalah sendiri tetapi siswa juga menguasai materi secara tuntas.

Helsi (2019) melaporkan hasil penelitianya bahwa penggunaan model guided discovery learning pada mata pelajaran Dasar Listrik dan Elektronika kompetensi hukum-hukum fenomena rangkaian kemagnitan lebih baik daripada model pembelajaran konvensional mirip dengan Susanto (2018) yang melaporkan penggunaan model pada pembelajaran Teknik Mekatronika, memberikan peningkatan hasil belajar siswa. Berdasarkan hal itu perlu dipastikan bagaimana dampak penggunaan model pembelajaran Discovery Learning pada pembelajaran siswa pada mata pelajaran dasar listrik dan elektronikia siswa elektronika kelas X Teknik Tenaga Listrik (TITL) di SMK.

Berdasarkan latar belakang masalah dan identifikasi masalah diatas maka dapat dirumuskan masalah sebagai berikut:

1. Bagaimanakah hasil belajar dasar listrik dan elektronika yang diajar dengan model pembelajaran Discovery Learning pada siswa Kelas X Teknik Instalasi Tenaga Listrik?

2. Bagaimanakah hasil belajar dasar listrik dan elektronika yang diajar dengan model pembelajaran Ekspositori pada siswa Kelas X Teknik Instalasi Tenaga Listrik?

3. Apakah hasil belajar dasar listrik dan elektronika yang menggunakan model pembelajaran Discovery Learning lebih tinggi dari hasil belajar yang menggunakan model pembelajaran ekspositori pada siswa Kelas X Teknik Instalasi Tenaga Listrik?

\section{Kerangka Teoritis}

Hasil belajar dapat dijelaskan dengan memahami dua kata yang membentuknya, yaitu "hasil" dan "belajar". Hasil merupakan akibat dari yang ditimbulkan karena berlangsungnya suatu proses kegiatan, sedangkan belajar adalah suatu proses kegiatan untuk memperoleh perubahan tingkah laku sebagai hasil pengalaman individu dalam interaksi dengan lingkungannya. Dengan demikian hasil belajar merupakan hasil proses kegiatan dari suatu interaksi antara individu dengan lingkungan dan tindak mengajar yang diakhiri dengan proses evaluasi hasil belajar. Menurut Sudarmanto (2008:161) Hasil belajar adalah "hasil belajar akhir tentang tinggi rendahnya nilai siswa selama mingikuti proses pembelajaran". Hasil belajar menurut sudjana (2009:22) adalah "komponen-komponen yang dimiliki siswa setelah ia menerima pengalaman belajarnya". Sedangkan menurut Suprijono (2010:7) "hasil belajar adalah perubahan perilaku secara keseluruhan bukan hanya salah satu aspek potensi kemanusiaan saja".

Discovery Learning adalah pengajaran dimana guru memberikan kebebasan bagi siswa untuk menemukan sesuatu secara sendiri dengan tujuan siswa dapat lebih mengerti secara dalam. Discovery Learning merupakan metode belajar berbasis pencarian, penyelidikan. Guru menciptakan situasi sehingga siswa dapat belajar sendiri, terlibat secara aktif dalam belajar untuk mengetahui konsep dan prinsip-prinsip. Siswa didorong untuk mempunyai pengalaman dan melakukan percobaan yang memungkinkan mereka menemukan prinsip - prinsip atau pengetahuan bagi dirinya. Hal ini menggambarkan keterlibatan siswa secara langsung pada persoalan - persoalnnya, untuk menemukan prinsip - prinsip atau jawaban lewat suatu percobaan. Dalam hal ini siswa dituntut untuk mampu mengasimilasikan sesuatu konsep atau prinsip. Adapun langkah-langkah dalam mengaplikasikan model Discovery Learning menurut Syah (2004) adalah sebagai berikut :

(a) Stimulation (stimulasi/memberikan rangsangan)

(b) Problem statement (pernyataan/identifikasi masalah)

(c) Data collection (pengumpulan data)

(d) Data processing (pengolah data)

(e) Verification (pembuktian)

(f) Generalization (menarik kesimpulan).

Pembelajaran ekspositori adalah intraksi antara guru dan siswa dalam rangka pencapaian tujuan pembelajaran. Menurut sudjana (dalam siringoringo, 2006) bahwa : metode ekspositori merupakan suatu 
cara penyampaian dengan lisan kepada sejumlah pendengar, kegiatan ini berpusat pada penceramah dan komunikasi yang terjadi satu arah. Dalam pembelajaran ekspositori siswa dipandang sebagai yang belum mengetahui suatu apapun dan hanya menerima bahan-bahan yang diberikan oleh guru. Guru adalah orang dewasa yang memiliki pengetahuan dan wewenang untuk menyampaikan pengetahuan itu kepada siswanya. Tujuan pembelajaran pada pemilihan ilmu pengetahuan. Oleh karna itu orang yang memiliki banyak ilmu pengetahuan dipandang arif bijaksana dan pandai. Menurut Direktorat Tenaga Kependidikan (2008:34) mengemukakan ada beberapa langkah dalam penerapan stategi pembelajaran ekspositori, antara lain :

1. Persiapan ( preparation).

2. Penyajian (Presentation).

3. Korelasi (Corretation).

4. Mengaplikasikan (Application).

\section{METODE}

SMK Negeri Percut Sei Tuan yang beralamat di Jl.Kolam No. 3 Medan Estate Kec. Percut Sei Tuan dan SMK Negeri 5 Medan yang beralamat di Jl.Timor No. 36 Gaharu Kec. Medan Timur, pelaksanaan penelitian dilakukan pada semester I(ganjil) T.P 2019/2020. Populasi dalam penelitian ini adalah siswa kelas X Program Keahlian Teknik Instalasi Tenaga Listrik di Sekolah Menengah Kejuruan (SMK) Negeri 1 Percut Sei Tuan dan Sekolah Menengah Kejuruan (SMK) Negeri 5 Medan pada mata pelajaran dasar listrik dan elektronika. Sampel di dilakukan secara acak dalam penelitian ini, sampel yang terpilih adalah X TITL 1 di SMK N. 1 Percut Sei Tuan (Eksperimen) dan X TITL 2 di SMK N. 5 Medan (Kontrol).

Jenis penelitian yang digunakan peneliti adalah penelitian eksperimen. Penelitian ini menggunakan desain non-equivalent control group design. Desain ini menggunakan 2 kelompok, yaitu kelas eksperimen dan kelas kontrol. Kelas eksperimen adalah kelompok yang mendapat perlakuan berupa penerapan model discovery learning sedangkan kelas kontrol adalah kelompok pengendali yaitu kelas mendapat perlakuan model ekspositori. Dalam desain ini, baik kelompok eksperimental maupun kelompok kontrol dibandingkan. Dua kelompok yang ada diberi pretes untuk mengetahui kemampuan awal siswa mengenai pelajaran yang disampaikan, kemudian diberikan perlakuan, dan terakhir diberikan postes untuk memperoleh gambaran tentang kemampuan yang dicapai setelah berakhirnya penyampaian pelajaran.

Instrument penelitian ini adalah evaluasi belajar berupa pre-test dan post - test dalam bentuk tes objektif pilihan berganda dan observasi. Tes ini berbentuk pilihan ganda dengan jumlah 40 soal dan empat pilihan jawaban untuk setiap soal. Kriteria penilaian adalah skor 1 untuk setiap soal yang dijawab benar dan skor 0 untuk setiap soal yang dijawab salah.

Setelah tes hasil belajar disusun, sebelum digunakan untuk menjaring data penelitian dahulu diuji cobakan untuk melihat keterandalan butir tes dengan cara yaitu diuji coba instrumen. Uji coba ini juga bertujuan untuk mendapatkan alat ukur yang benar-benar dapat menjaring data yang akurat aagr kesimpulan yang diambil sesuai dengan kenyataan. Sebelum pengumpulan data dilakukan terlebih dilakukan uji coba instrumen penelitian yang dilaksanakan di SMKN 1 Percut Sei Tuan. Untuk mengetahui validitas tes hasil belajar dasar listrik dan elektronika digunakan korelasi point biserial. Rumus yang digunakan dalam menghitung instrumen reliabilitas dalam penelitian ini yaitu rumus Kuder dan Richardson $\mathrm{K}-\mathrm{R} 20$. Bilangan yang menunjukkan sukar dan mudahnya suatu soal disebut indeks kesukaran (difficulty index). Besarnya indeks kesukaran antara 0,00 sampai 1,00. Daya pembeda butir soal adalah kemampuan suatu soal untuk membedakan antara siswa yang pandai (berkemampuan tinggi) dengan siswa yang berkemampuan rendah.

Data hasil belajar siswa yang terkumpul selanjutnya akan dianalisis guna mencapai hasil yang maksimal. Langkah-langkah untuk menganalisis data adalah sebagai berikut :

1. Menghitung Nilai Rata-rata, Standar Deviasi, dan Varians

2. Uji Normalitas

3. Uji Tingkat Homogenitas

4. Uji Hipotesis 


\section{HASIL DAN PEMBAHASAN}

Setelah penelitian selesai langkah selanjutnya adalah menganalisis data. Penelitian. Sampel penelitian diambil 2 kelas dari sekolah yang berbeda yaitu kelas X TITL 1 (eksperimen) di SMK N Percut 1 yang diberikan perlakuan model pembelajaran Discovery Learning dan kelas X TITL 2 (Control) yang diberikan perlakuan model pembelajaran Ekspositori di SMK Negeri 5 Medan. Berdasarkan hasil tes penelitiaan, hasil posttest pada kelas yang diberikan perlakuan model pembelajaran Discovery Learning diperoleh skor terendah 60 dan skor tertinggi 96 dengan nilai ratarata 81,5. Hasil posttest pada kelas yang diberikan perlakuan model pembelajaran Ekspositori diperoleh skor terendah 44 dan skor tertinggi 92 dengan nilai rata-rata 68,3.

Kelas yang diberikan perlakuan model pembelajaran Discovery Learning pada pertemuan pertama diberi pretest dan pada pertemuan terakhir diberi posttest untuk mengetahui hasil belajar siswa. Penilaian hasil pretest dan posttest kelas yang diberikan perlakuan modelpembelajaran Discovery Learning diperoleh rentang skor 0 sampai 100.

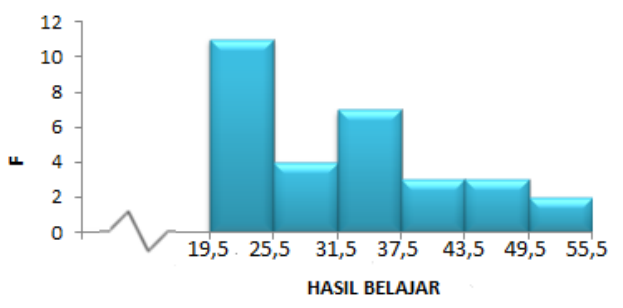

Gambar 1. Histogram data hasil belajar pretest kelas yang diberikan perlakuan model pembelajaran Discovery Learning (eksperimen)

Dari histogram pretest pada kelas yang diberikan perlakuan model pembelajaran Discovery Learning (eksperimen) diatas menunjukkan bahwa, kemampuan atau pengetahuan awal siswa pada mata pelajaran dasar listrik dan elektronika untuk materi menganalisis teorema rangkaian listrik arus searah masih kurang. Hal itu ditunjukkan nilai tertinggi siswa adalah 56 sedangkan nilai terendah adalah 20. Nilai rata-rata untuk pretest kelas yang diberikan perlakuan model pembelajaran Discovery Learning (eksperimen) adalah 33,1. Ini menunjukkan bahwa pengetahuan awal siswa pada materi menganalisis teorema rangkaian listrik arus searah masih kurang, maka perlu diberikan perlakuan khusus untuk menaikkan pengetahuan mereka.

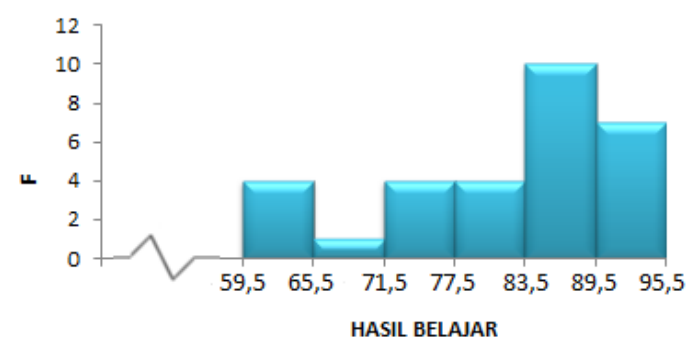

Gambar2. Histogram data hasil belajar posttest kelas yang diberikan perlakuan model pembelajaran Discovery Learning (eksperimen)

Setelah diberikan perlakuan model pembelajaran Discoveri Learning, maka hasil belajar meningkat. Hal itu dapat dilihat dari nilai tertinggi pada kelas tersebut adalah 96 sedangkan nilai terrendah adalah 60. Nilai rata-rata di kelas tersebut adalah 81,5. Ini menunjukkan bahwa dengan perlakuan model pembelajaran Discovery Learning dapat meningkatkan hasil belajar siswa.

Kelas yang diberikan perlakuan model pembelajaran Ekspositori pada pertemuan pertama diberi pretest dan pada pertemuan terakhir diberi posttest untuk mengetahui hasil belajar siswa. Penilaian hasil pretest dan posttest kelas yang diberikan perlakuan model pembelajaran Ekspositori diperoleh rentang skor 0 sampai 100. 


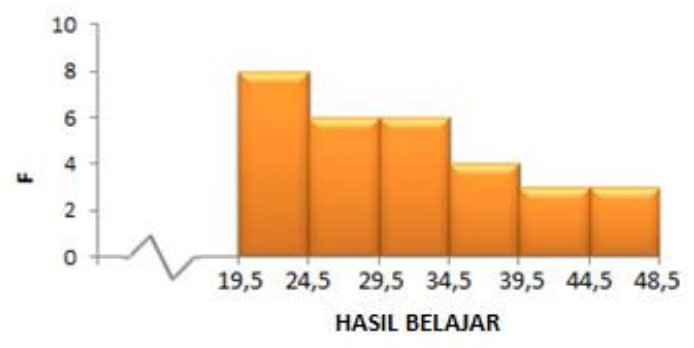

Gambar3. Histogram data hasil belajar pretest kelas yang diberikan perlakuan model pembelajaran ekspositori (kontrol)

Dari histogram pretest pada kelas yang diberi perlakuan model pembelajara ekspositori diatas menunjukkan bahwa, kemampuan atau pengetahuan awal siswa pada mata pelajaran dasar listrik dan elektronika untuk materi menganalisis teorema rangkaian listrik arus searah masih kurang. Hal itu ditunjukkan nilai tertinggi siswa adalah 48 sedangkan nilai terendah adalah 20 . Nilai rata-rata untuk pretest kelas yang diberi perlakuan model pembelajara ekspositori adalah 31,6. Ini menunjukkan bahwa pengetahuan awal siswa pada materi menganalisis teorema rangkaian listrik arus searah masih kurang, maka perlu diberikan perlakuan khusus untuk menaikkan pengetahuan mereka.

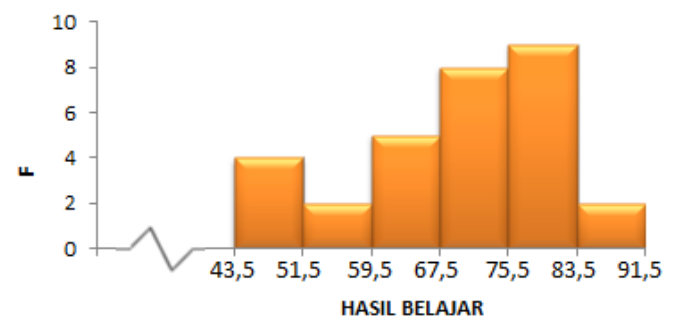

Gambar 4. Histogram data hasil belajar posttest kelas yang diberikan perlakuan model pembelajaran ekspositori (kontrol)

Setelah diberikan perlakuan model pembelajaran ekspositori, maka hasil belajar meningkat. Hal itu dapat dilihat dari nilai tertinggi pada kelas tersebut adalah 92 sedangkan nilai terrendah adalah 44 . Nilai rata-rata di kelas tersebut adalah 68,3. Ini menunjukkan bahwa dengan perlakuan model pembelajaran ekspositori dapat meningkatkan hasil belajar siswa.

Uji normalitas data menggunakan uji Lilliefors untuk melihat kenormalan data penelitian. Hasil uji normalitas data kedua kelas ditunjukkan dalam Tabel berikut.

Tabel 1. Hasil Uji Normalitas

\begin{tabular}{|c|c|l|c|c|c|c|}
\hline $\begin{array}{c}\mathrm{N} \\
\mathrm{o}\end{array}$ & Data & \multicolumn{1}{|c|}{ Kelas } & $\mathrm{L}_{\text {hitung }}$ & $\mathrm{A}$ & $\mathrm{L}_{\text {tabel }}$ & Kes \\
\hline \multirow{2}{*}{1.} & \multirow{2}{*}{$\begin{array}{c}\text { Post } \\
\text { test }\end{array}$} & $\begin{array}{l}\text { Kelas eksperimen } \\
\text { (Discovery Learning) }\end{array}$ & 0,131 & 5 & 0,164 & Normal \\
& $\begin{array}{l}\text { Kelas kontrol } \\
\text { (ekspositori) }\end{array}$ & 0,116 & & 0,164 & Normal \\
\hline
\end{tabular}

Tabel diatas menunjukkan bahwa data posttest kelas yang diberi perlakuan model pembelajaran discovery learning dan ekspositori Lhitung $\leq$ Ltabel dengan $\alpha=0.05$, sehingga berdistribusi normal.

Uji homogenitas data menggunakan uji kesamaan dua varians pada taraf signifikan $\alpha=5 \%$. Hasil perhitungan uji homogenitas tersebut ditunjukkan pada Tabel berikut ini: 
Tabel 2. Hasil Uji Homogenitas

\begin{tabular}{|c|l|c|c|c|c|c|}
\hline Data & \multicolumn{1}{|c|}{ Kelas } & Varians & $\mathrm{F}_{\text {hitung }}$ & $\mathrm{A}$ & $\mathrm{F}_{\text {tabel }}$ & Kes \\
\hline \multirow{3}{*}{ Posttest } & $\begin{array}{l}\text { Kelas eksperimen (Discovery } \\
\text { Learning) }\end{array}$ & 108,7 & 1,55 & $\begin{array}{c}5 \\
\%\end{array}$ & 1,86 & Homogen \\
\cline { 2 - 4 } & Kelas kontrol (ekspositori) & 168,7 & & \\
\hline
\end{tabular}

Hasil perhitungan uji homogenitas posttest diperoleh nilai $F_{\text {hitung }}=1,55$. Pada taraf signifikasi $\alpha=0,05$ diperole harga $F_{\text {tabel }}=1,86$. Karena $F_{\text {hitung }} \leq F_{\text {tabel }}$ maka data posttest kedua sampel adalah homogen.

Uji hipotesis yang digunakan adalah uji t-hitung taraf signifikan $\alpha=0.05$ derajat kebebasan $(\mathrm{dk})\left(\mathrm{n}_{1}\right.$ $\left.+\mathrm{n}_{2}-2\right)$ dengan kriteria Jika $\mathrm{t}_{\text {hitung }} \leq \mathrm{t}_{\text {tabel }}$ maka $\mathrm{H}_{\mathrm{o}}$ diterima dan $\mathrm{H}_{\mathrm{a}}$ ditolak. Dan jika $\mathrm{t}_{\text {hitung }}>\mathrm{t}_{\text {tabel }}$ maka $\mathrm{H}_{\mathrm{a}}$ diterima dan $\mathrm{H}_{\mathrm{o}}$ ditolak.

Tabel 3. Hasil Uji Hipotesis

\begin{tabular}{|c|c|c|c|c|c|c|}
\hline No & Data Postest & $\begin{array}{l}\text { Nilai Rata- } \\
\text { Rata }\end{array}$ & $t_{\text {hitung }}$ & $\alpha$ & $\mathrm{t}_{\text {tabel }}$ & Kesimpulan \\
\hline 1 & $\begin{array}{l}\text { Kelas } \quad \text { eksperimen } \\
\text { (Discovery Learning) }\end{array}$ & 81,5 & \multirow{2}{*}{$\begin{array}{c}15,6 \\
2\end{array}$} & \multirow{2}{*}{$\begin{array}{l}5 \\
\%\end{array}$} & \multirow{2}{*}{1,672} & \multirow{2}{*}{$\begin{array}{l}\text { Ha diterima, } \\
\text { Ho ditolak }\end{array}$} \\
\hline 2 & Kelas kontrol (ekspositori) & 68,3 & & & & \\
\hline
\end{tabular}

Berdasarkan Tabel di atas, kelas yang diberi perlakuan model pembelajaran discovery learning memperoleh nilai rata-rata hasil belajar adalah 81,5 dan kelas yang diberi perlakuan model pembelajaran eskpositori memperoleh hasil belajar dengan nilai rata-rata 68,3. Data menunjukkan bahwa $t_{\text {hitung }} \geq t_{\text {tabel }}$ $(15,62 \geq 1,672)$, sehingga dapat disimpulkan bahwa Ha diterima dan Ho ditolak, yaitu bahwa hasil belajar pada mata pelajaran dasar listrik dan elektronika yang menggunakan model pembelajaran Discovery Learning lebih tinggi daripada menggunakan model pembelajaran Ekspositori.

Berdasarkan analisis data hasil belajar pada mata pelajaran dasar listrik dan elektronika, dapat diketahui bahwa terdapat perbedaan signifikan (positif) antara hasil belajar siswa pada mata pelajaran dasar listrik dan elektronika yang diberi perlakuan model pembelajaran discovery learning dengan hasil belajar siswa pada mata pelajaran dasar listrik dan elektronika yang diberi perlakuan model pembelajaran ekspositori.

Hasil penelitian yang telah dilakukan diperoleh bahwa hasil belajar siswa kelas yang diberi perlakuan model pembelajaran Discovery Learning dan kelas yang diberi perlakuan model pembelajaran ekspositori berdistribusi normal. Pengujian homogenitas sesudah pemberian perlakuan menunjukkan bahwa kedua kelompok data memiliki varians yang homogen. Kelas yang diberi perlakuan model pembelajaran Discovery Learning diperoleh nilai rata-rata 81,5 dengan standar deviasi 10,2. Sedangkan kelas yang diberi perlakuan model pembelajaran eksposirori diperoleh nilai rata-rata 68,3 dengan standar deviasi 12,7. Bila dilihat dari nilai posttest model pembelajaran Discovery Learning memiliki hasil belajar yang lebih tinggi daripada menggunakan model pembelajaran Ekspositori pada mata pelajaran dasar listrik dan elektronika. Berikut ini adalah diagram yang menunjukkan nilai pretest dan posttest kelas yang diberi perlakuan model pembelajaran Discovery Learning dan ekspositori.

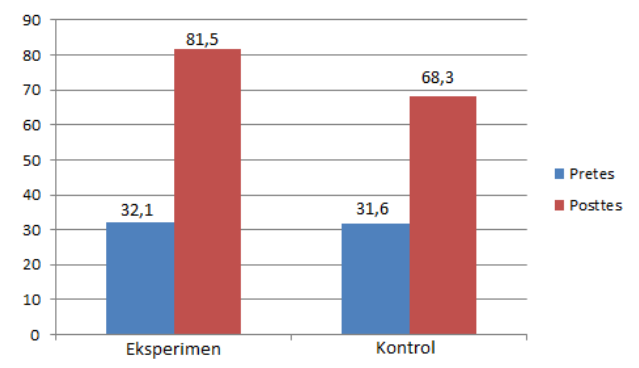

Gambar 5. Diagram nilai rata-rata kelas eksperimen dan kontrol 
Berdasarkan gambar di atas dan hasil perhitungan yang telah dilakukan bahwa nilai rata-rata hasil belajar siswa pada mata pelajaran dasar listrik dan elektronika yang diberi perlakuan model pembelajaran Discovery Learning dan ekspositori ada perbedaan yang signifikan.

Pengujian hipotesis dilakukan untuk melihat perbedaan hasil belajar siswa yang diberi perlakuan model pembelajaran Discovery Learning dan ekspositori. Pengujian hipotesis yang digunakan adalah uji $t$, dengan taraf signifikan 5\%, dimana Ha diterima atau Ho ditolak jika $t_{\text {hitung }}>t_{\text {tabel }}$ dan Ho diterima atau Ha ditolak jika $t_{\text {hitung }} \leq \mathrm{t}_{\text {tabel }}$. Harga $\mathrm{t}_{\text {hitung }}$ yang diperoleh adalah 15,62 dan data $\mathrm{t}_{\text {tabel }}$ diketahui 1,672. Maka, kriteria pengujian data diperoleh $t_{\text {hitung }} \geq t_{\text {tabel }}$ yaitu $15,62 \geq 1,672$. Oleh karena itu, dapat disimpulkan bahwa dengan menggunakan model pembelajaran Discovery Learning hasil belajar siswa lebih tinggi daripada menggunakan model ekspositori pada mata pelajaran dasar listrik dan elektronika.

\section{SIMPULAN}

Berdadarkan hasil penelitian dan pembahasan dapat disimpulkan bahwa :

1. Hasil belajar siswa pada mata pelajaran dasar listrik dan elektronika yang diberi perlakuan model pembelajaran discovery learning diperoleh nilai rata-rata sebesar 81,5 dengan dengan nilai tertinggi adalah 96 dan nilai terendah adalah 60 .

2. Hasil belajar siswa pada mata pelajaran dasar listrik dan elektronika yang diberi perlakuan model pembelajaran ekspositori diperoleh nilai rata-rata sebesar 68,3 dengan dengan nilai tertinggi adalah 92 dan nilai terendah adalah 44 .

3. Hasil belajar siswa yang diberi perlakuan model pembelajaran discovery learning lebih tinggi dari hasil belajar siswa yang yang diberi perlakuan model pembelajaran ekspositori. Hal ini dibuktikan dengan hasil uji t yaitu bahwa thitung > ttabel $(15,62>1,672)$, sehingga $\mathrm{HO}$ ditolak dan $\mathrm{Ha}$ diterima.

Berdasarkan hasil analisis data dan kesimpulan yang dikemukakan sebelumnya, makas penulis mengajukan saran sebagai berikut:

1. Model pembelajaran Discovery Learning dapat diterapkan pada kompetensi yang ada pada mata pelajaran dasar listrik dan elektronika. Siswa akan kelihatan lebih aktif dikarenakan interaksi antar teman sebayadimana dalam hal ini siswa merasa tidak akan segan-segan untuk bertanya dan menggali informasi dengan temannya. Hal tersebut akan merangsang siswa unutk lebih berpikir kritis dalam menyelesaikan tugas atau masalah yang diberikan dengan baik.

2. Model Ekspositori dapat juga diterapkan pada kompetensi yang ada pada mata pelajaran dasar listrik dan elektronika meskipun pada saat proses pembelajaran hanya berfokus pada guru.

3. Model pembelajaran Discovery Learning dan Ekspositori dapat dijadikan alternatif sebagai variasi pada proses pembelajaran.

\section{DAFTAR PUSTAKA}

Abdullah, Sani Ridwan. (2014). Pembelajaran Saintifik untuk Kurikulum 2013. Jakarta Bumi Aksara

Arikunto, S. (2012). Dasar-Dasar Evaluasi Pendidikan. Jakarta : Bumi Aksara.

Budiningsih, Asri. (2009). Belajar dan Pembelajaran. Rineka Cipta. Jakaerta

Cruickshank, D. R. Jengkins. D. B,. \& Metcelf, K. K. (2009). The Act Of Teaching. New York : The Mcgraw-Hill Companies Inc

Direktur Jenderal Pendidikan Menengah Kemendikbud RI Nomor 7013/D/KP/2013 Tanggal 4 Desember 2013 tentang Spektrum Keahlian Pendidikan Menengah Kejuruan.

Hariyanti, Aan Rini. (2016). Studi Perbandingan Hasil Belajar Matematika dengan Menggunakan Model Project Based Learning dan Discovery Learning pada Materi Persamaan Linear Satu Variabel Kelas VII SMP N 19 Kota Jambi . Jambi: FKIP Universitas Jambi.

Helsi M.P, Effendi H (2019). Pengaruh Model Pembelajaran Guided Discovery Learning Terhadap Hasil Belajar Siswa pada Mata Pelajaran Dasar Listrik dan Elektronika. JTEV (Jurnal Teknik Elektro dan Vokasional. 05(02).

Hosnan. (2014). Pendekatan Saintifik dan Kontekstual dalam Pembelajaran Abad 21. Bogor : Graha Indonesia

Kementrian Pendidikan dan Kebudayaan. (2014). Modul Pelatihan Implementasi Kurikulum 2013 SMP Bahasa Inggris. Jakarta: Badan Pengembangan Sumberdaya Manusia Pendidikan Dan Kebudayaan Dan Penjaminan Mutu Pendidikan Kementrian Pendidikan Dan Kebudayaan.

Klahr, D., \& Nigam, M. (2004). The Equivalence of Learning Paths in Early Science Instruction : Effects of Direct Instruction and Discovery Learning. Psychological science. 15(10). 
Mohammad Takdir Ilahi, (2012). Pembelajaran Discovery Strategy Skill. Penerbit Diva Press.

Rohani. (2004). Pengelolaan Pengajaran. Jakarta : Rineka Cipta

Slameto, (2013:54). Belajar dan Faktor-Faktor yang Mempengaruhinya. Jakarta: Rineka Cipta

Slavin, E Roberts. (2010). Cooperative Learning Teori, Riset, dan Praktik: Cetakan VIII. Bandung : Nusa Media

Syaiful Sagala. (2003). Konsep Dan Makna Pembelajaran. Bandung: Alfabeta

Sudarmanto. 2008. Meningkatkan Hasil belajar Dengan Pembelajaran Inovatif. Jurnal Pendidikan 2008:161

Sudjana. (2009). Metoda Statistika. Bandung : Tarsito

Sudjana, Nana. (2009). Dasar-Dasar Proses Belajar Mengajar. Bandung : Sinar Baru Algesindo

Sugiyono, (2016). Metode Penelitian Kuantitatif Kualitatif dan R\&D. Bandung: Alfabeta

Suherman, Dkk. (2001). Common Texbook Strategi Pembelajaran Matematika

Susanto J, Zulwisli (2018). Pengaruh Penerapan Model Pembelajaran Discovery Learning Terhadap Hasil Belajar Siswa Pada Mata Pelajaran Dasar Listrik Dan Elektronika Kelas X Teknik Mekatronika Smk Negeri I Sumatera Barat. Jurnal Vokasional Teknik Elektronika dan Informatika. 6(2).

Suprijono, Agus. (2010:6).Cooperative Learning. Surabaya : Pustaka Pelajar

Widi, Restu Kartiko. 2010. Asas Metodologi Penelitian. Yogyakarta: Graha Ilmu. 